\title{
A randomised controlled trial on roles of prostaglandin E1 nebulization among patients undergoing one lung ventilation
}

Pengyi $\mathrm{Li}^{\dagger}$, Lianbing $\mathrm{Gu}^{\dagger}$, Jing Tan ${ }^{\dagger}$, Zhenghuan Song, Qingming Bian, Dian Jiao, Zeping Xu and Lijun Wang ${ }^{*}$

\begin{abstract}
Background: Prostaglandin E1 (PGE1) has been reported to maintain adequate oxygenation among patients under $60 \% \mathrm{FiO}_{2}$ one-lung ventilation (OLV). This research aimed to explore whether PGE1 is safe in pulmonary shunt and oxygenation under $40 \% \mathrm{FiO}_{2}$ OLV and provide a reference concentration of PGE1.

Methods: Totally 90 esophageal cancer patients treated with thoracotomy were enrolled in this study, randomly divided into three groups ( $\mathrm{n}=30 / \mathrm{group})$ : Group A (60\% $\mathrm{FiO}_{2}$ and $0.1 \mu \mathrm{g} / \mathrm{kg}$ PGE1), Group B ( $40 \% \mathrm{FiO}_{2}$ and $0.1 \mu \mathrm{g} / \mathrm{kg}$ PGE1), and Group C (40\% $\mathrm{FiO}_{2}, 0.2 \mu \mathrm{g} / \mathrm{kg}$ PGE1). Primary outcomes were oxygenation and pulmonary shunt during OLV. Secondary outcomes included oxidative stress after OLV.
\end{abstract}

Results: During OLV, patients in Group $\mathrm{C}$ and $\mathrm{B}$ had lower levels of $\mathrm{PaO}_{2}, \mathrm{SaO}_{2}, \mathrm{SpO}_{2}, \mathrm{MAP}$, and Qs/Qt than those in Group A $(P<0.05)$. At T2 (OLV 10 min), patients in Group $C$ and $B$ exhibited a lower level of $\mathrm{PaO}_{2} / \mathrm{FiO}_{2}$ than those in Group A, without any statistical difference at other time points. The IL-6 levels of patients in different groups were different at T8 ( $F=3.431, P=0.038$ ), with IL-6 in Group C being lower than that in Group B and A. MDA levels among the three groups differed at T5 $(F=4.692, P=0.012)$ and $T 7(F=5.906, P=0.004)$, with the MDA level of Group $C$ being lower than that of Group B and A at T5, and the MDA level of Group C and B being lower than that of Group A at T7. In terms of TNF-a level, patients in Group C had a lower level than those in Group B and A at T8 ( $F=3.598, P=0.033)$. Compared with patients who did not use PGE1, patients in Group C had comparable complications and lung infection scores.

Conclusion: The concentration of $\mathrm{FiO}_{2}$ could be reduced from 60 to $40 \%$ to maintain oxygenation. $40 \%$ $\mathrm{FiO}_{2}+0.2 \mu \mathrm{g} / \mathrm{kg}$ PGE1 is recommended as a better combination on account of its effects on the inflammatory factors.

Trial registration: Chictr.org.cn identifier: ChiCTR1800018288, 09/09/2018.

Keywords: Prostaglandin E1, One-lung ventilation, $40 \% \mathrm{FiO}_{2}$, Randomised controlled trial

*Correspondence: wangljun520@163.com

†Pengyi Li, Lianbing Gu and Jing Tan contributed equally to this work Department of Anesthesiology, Jiangsu Cancer Hospital and Jiangsu Institute of Cancer Research, The Affiliated Cancer Hospital of Nanjing Medical University, No. 42 Baiziting, Xuanwu District, Nanjing 210009, Jiangsu, China

\section{Background}

Open radical esophagectomy with extended lymph node dissection is vital for treating esophageal cancer (EC), whether EC is early and locally advanced $[1,2]$. One-lung ventilation (OLV) has been extensively used throughout thoracic surgery, being conducive to surgical exposure [3]. However, OLV can decrease the partial pressure of 
arterial oxygen $\left(\mathrm{PaO}_{2}\right)$ and lead to hypoxemia by increasing intrapulmonary shunts and alveolar death space [4, 5]. Furthermore, it has been reported that hypoxemia is associated with an increased risk of complications, such as cognitive impairment, atrial fibrillation, renal failure, and pulmonary hypertension [6,7]. Therefore, the prevention and treatment of hypoxemia during OLV is an essential part in intraoperative anesthesia management.

A high fraction of inspiration $\mathrm{O}_{2}\left(\mathrm{FiO}_{2}\right)$ has been usually adopted to prevent hypoxemia in clinical practice [8]. However, a recent large multicenter cohort study found that high $\mathrm{FiO}_{2}\left(\mathrm{FiO}_{2}>60 \%\right)$ could promote expiratory pulmonary collapse and atelectasis, with long-term high $\mathrm{FiO}_{2}$ exposure being associated with worsening oxygenation index [9]. According to current protective ventilation strategies, the $\mathrm{FiO}_{2}$ should be controlled to the lowest level in the case of sufficient oxygenation, without specific reference of $\mathrm{FiO}_{2}$ concentrations [10]. Prostaglandin E1 (PEG1), a kind of selective pulmonary arterial vasodilator, has been reported to decrease pulmonary shunts and increase $\mathrm{PaO}_{2}$ during OLV [11], with a debated optimal dosage [12-14] Our previous study has demonstrated that PGE1 can maintain adequate oxygenation in patients under $60 \% \mathrm{FiO}_{2} \mathrm{OLV}$ [15]. To the best of our knowledge, the effects of PGE1 on pulmonary shunt and oxygen supply of patients under $40 \% \mathrm{FiO}_{2} \mathrm{OLV}$ are still unclear.

Herein, a randomized controlled trial was designed to explore the effect of PGE1 nebulization of ventilated lungs under $40 \% \mathrm{FiO}_{2}$ OLV on maintaining adequate oxygenation based on 90 patients from the Affiliated Cancer Hospital of Nanjing Medical University between 2015 and 2017.

\section{Methods}

\section{Study population}

Patients with EC scheduled to undergo selective open radical resection were recruited from Affiliated Cancer Hospital of Nanjing Medical University between 2015 and 2017. Diagnosis of EC patients was based on clinical, laboratory, histopathological, and gastroscopy assessment. Exclusion Criteria: (1) percutaneous oxygen saturation $\left(\mathrm{SpO}_{2}\right)$ was below $90 \%$ during the trial and $\mathrm{SpO}_{2}$ did not rise to more than $90 \%$ or further reduced to less than $88 \%$ within 3 min; (2) severe arrhythmia and hemodynamic instability occurred during the whole surgery; (3) surgical duration was more than $6 \mathrm{~h}$ or less than $1 \mathrm{~h}$; (4) liver dysfunction and kidney dysfunction were determined based on laboratory test parameters, history of coronary heart disease, cerebral infarction and glaucoma. Random number table was used for group assignment (Fig. 1): Group A $\left(\mathrm{FiO}_{2}=60 \%\right.$, PGE1 dose $=0.1 \mu \mathrm{g} / \mathrm{kg}$, $\mathrm{n}=30)$, Group $\mathrm{B}\left(\mathrm{FiO}_{2}=40 \%\right.$, PGE1 dose $=0.1 \mu \mathrm{g} / \mathrm{kg}$, $\mathrm{n}=30)$, Group $\mathrm{C}\left(\mathrm{FiO}_{2}=40 \%\right.$, PGE1 dose $=0.2 \mu \mathrm{g} / \mathrm{kg}$, $\mathrm{n}=30$ ). This randomized controlled clinical trial was registered at chictr.org.cn (identifier: ChiCTR1800018288, 09/09/2018), approved by the Ethics Committee of the Nanjing Medical University [2017-550].

\section{Anesthesia and intervention}

After completing pre-operation preparation, all participants underwent general anesthesia and intubation with a left-side double-lumen tube (DLT). Thirty minutes before admission to the operating room, patients received phenobarbital $0.1 \mathrm{~g}$ and atropine $0.5 \mathrm{mg}$. A central venous catheter was inserted via the right internal jugular vein. Midazolam $(0.05 \mathrm{mg} /$ $\mathrm{kg})$, fentanyl $(3-4 \mu \mathrm{g} / \mathrm{kg})$, propofol $(1 \mathrm{mg} / \mathrm{kg})$, and cis-atracurium $(0.2 \mathrm{mg} / \mathrm{kg})$ were adopted for anesthesia induction. A left-side DLT was then inserted, with fiber bronchoscopy being used to confirm its position. Parameters of the ventilator were set as follows: tidal volume (VT), $6-8 \mathrm{ml} /$ predicted body weight; respiratory rate (RR), $12-14 / \mathrm{min}$; the ratio of inspiratory to expiratory time (I:E rate), 1:2; end-tidal carbon dioxide $\left(\mathrm{ETCO}_{2}\right), 35-45 \mathrm{mmHg} ; \mathrm{FiO}_{2}, 60 \%$; positive endexpiratory pressure (PEEP), $5 \mathrm{cmH}_{2} \mathrm{O}$. The settings of VT and PEEP were kept initially unchanged throughout OLV. When the oxygen partial pressure dropped rapidly below $90 \%$, I:E rate was adjusted to $1: 1.5$ by

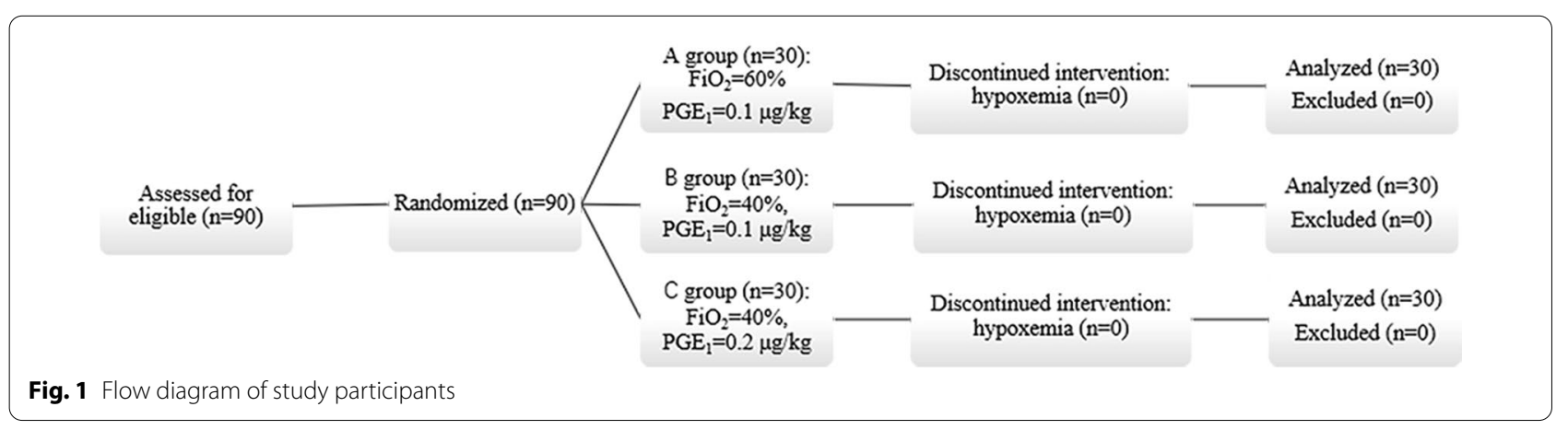


increasing RR. If $\mathrm{SpO}_{2}$ did not rise above $90 \%$ or further dropped below $88 \%$ within $3 \mathrm{~min}, 100 \% \mathrm{O}_{2}$ ventilation, continuous positive airway pressure (CPAP) on non-ventilated side lungs, and resumed ventilation of double lungs were performed in sequence if necessary. The unventilated lungs were directly connected to the room air. Group B and Group C were treated with $40 \%$ $\mathrm{FiO}_{2}$ throughout the surgery. Depth of anesthesia was monitored by the bispectral index (BIS), keeping it between 40 and 60 .

After confirming the placement of a DLT with a fiberoptic bronchoscope, the patient was repositioned to a right lateral decubitus position, and double lungs were ventilated to nebulization. All the three groups were treated with PGE1 (Beijing Tide Pharmaceutical Co., Ltd., $10 \mu \mathrm{g} / 2 \mathrm{ml}$, diluted to $10 \mathrm{ml}$ with normal saline) nebulization to the right lung through a reconstructed breathing circuit, all nebulization being maintained for $10 \mathrm{~min}$. The Yuyue 402A ultrasonic nebulizer was modified in 2 steps: firstly, seal the bottom of the sprayer tank to remove the air inlet; secondly, isolate the two original atomizer outlets to ensure that one of the exits was a new intake, and the other was the only outlet towards the patients. The device was then connected to the designated breathing circuit [16].

\section{Observed indicators}

$\mathrm{PaO}_{2}$, arterial oxygen saturation $\left(\mathrm{SaO}_{2}\right), \mathrm{SpO}_{2}$, and arterial partial pressure of carbon dioxide $\left(\mathrm{PaCO}_{2}\right)$ were determined from the artery and venous blood samples, which were taken at post-anesthesia/pre-nebulization (T1), OLV $10 \mathrm{~min}$ (T2), OLV $15 \mathrm{~min}$ (T3), OLV $30 \mathrm{~min}$ (T4), OLV 60 min (T5), OLV 120 min (T6). Mean arterial pressure (MAP) and airway pressure (PAW) were also recorded. Shunt fraction was calculated using the following formula:

$$
\begin{aligned}
\mathrm{Qs} / \mathrm{Qt}= & \left(\mathrm{CcO}_{2}-\mathrm{CaO}_{2}\right) /\left(\mathrm{CcO}_{2}-\mathrm{CvO}_{2}\right)[17,18] \\
\mathrm{CaO}_{2}= & \mathrm{PaO}_{2} * 0.0031+\left(\mathrm{Hb} * 1.36 * \mathrm{SaO}_{2}\right) \\
\mathrm{CvO}_{2}= & \left(\mathrm{PvO}_{2} * 0.0031\right)+\left(\mathrm{Hb} * 1.36 * \mathrm{SvO}_{2}\right) \\
\mathrm{CcO}_{2}= & {\left[\mathrm{FiO}_{2} *\left(\mathrm{P}_{\mathrm{B}}-\mathrm{P}_{\mathrm{H}_{2} \mathrm{O}}\right)-\mathrm{PaCO}_{2} / \mathrm{R}\right] } \\
& * 0.0031+(\mathrm{Hb} * 1.36)
\end{aligned}
$$

$\mathrm{CcO}_{2}$, pulmonary capillary blood oxygen content; $\mathrm{CaO}_{2}$, arterial blood oxygen content; $\mathrm{CvO}_{2}$, mixed venous blood oxygen content; $\mathrm{PvO}_{2}$, mixed venous oxygen partial pressure; $\mathrm{SvO}_{2}$, mixed venous oxygen saturation, we replaced $\mathrm{SvO}_{2}$ with central venous oxygen saturation $\left(\mathrm{ScvO}_{2}\right) ; \mathrm{P}_{\mathrm{B}}$, atmospheric pressure $(760 \mathrm{mmHg}) ; \mathrm{P}_{\mathrm{H} 2 \mathrm{O}}, 37{ }^{\circ} \mathrm{C}$ water vapor pressure $(47 \mathrm{mmHg})$; R, respiratory quotient $(0.8)$.
Measurement of serum malondialdehyde (MDA) and superoxide dismutase (SOD), Tumor necrosis factor-a (TNF-a), and interleukin 6 (IL-6)

Venous blood sampling through the central line was collected at $\mathrm{T} 1, \mathrm{~T} 5,30 \mathrm{~min}$ after restarting twolung ventilation (TLV) (T7) and $24 \mathrm{~h}$ after surgery (T8). After centrifugation (3000 rpm, $\left.4{ }^{\circ} \mathrm{C}, 20 \mathrm{~min}\right)$, the serum was stored at $-80{ }^{\circ} \mathrm{C}$ until being assayed. According to the manufacturer's instructions, the concentrations of MDA, SOD, TNF- $\alpha$, and IL- 6 were measured by human MDA, SOD, TNF- $\alpha$, and IL- 6 ELISA Kits.

\section{Postoperative characteristics}

Clinical pulmonary infection score (CPIS) [19], complications (pleural effusion, pneumothorax, anastomotic leakage and incision infection), length of stay in the hospital or ICU, and the grade of wound healing were used as our prognostic indicators.

\section{Outcomes}

The primary outcomes were oxygenation and pulmonary shunt during OLV, including the observed and measurement indicators of $\mathrm{PaO}_{2}, \mathrm{PaO}_{2} / \mathrm{FiO}_{2}$ and $\mathrm{Qs} /$ Qt, which were determined at T2-T6. Secondary outcomes were oxidative stress after OLV, including MDA, SOD, TNF- $\alpha$, and IL- 6 at T1, T5, T7 and T8.

\section{Statistical analysis}

All data analyses were performed by R4.0.3. At least 24 patients were required in each group to achieve a power of 0.8 and a two-sided Alpha level of 0.05 . Thirty patients were included in each group considering the drop-out rate of $20 \%$. The measurement data were expressed as mean \pm standard deviation $(\mathrm{M} \pm \mathrm{SD})$ or median [interquartile range, $\mathrm{M}\left(\mathrm{Q}_{1}, \mathrm{Q}_{3}\right)$ ], and intergroup analysis was made by one-way ANOVA, Kruskal-Wallis rank test, or repeated-measures ANOVA of three factors, as appropriate. In addition, Student-Newman-Keuls (SNK) was used for comparisons between groups at each time point. Counting data was tested by the chi-square test. $P<0.05$ was considered statistically significant.

\section{Results \\ Baseline characteristics}

A total of 90 patients [71 (78.89\%) male, 19 (21.11\%) females] were enrolled and randomly divided into three groups, with an average age of $(63.32 \pm 6.46)$ years old (Table 1). No patient developed hypoxemia among the two groups. No significant differences in gender, age, 
Table 1 Basic situation of studied patients [n (\%)/Mean \pm SD]

\begin{tabular}{ll}
\hline Characteristic & All $(\mathbf{n}=\mathbf{9 0})$ \\
\hline Gender, $\mathrm{n}(\%)$ & \\
$\quad$ Male & $71(78.89)$ \\
$\quad$ Female & $19(21.11)$ \\
Age, year & $63.32 \pm 6.46$ \\
BMl, $\mathrm{kg} / \mathrm{m}^{2}$ & $23.16 \pm 2.91$ \\
Duration of surgery, min & $209.20 \pm 60.92$ \\
Duration of OLV, min & $173.57 \pm 50.75$ \\
\hline
\end{tabular}

BMI, Body mass index; OLV, one-lung ventilation

BMI, duration of surgery, and duration of OLV were observed among those patients $(P>0.05)$. Table 2 shows the clinical characteristics of all the patients.

\section{Effects of PGE1 nebulization of ventilated lungs under different $\mathrm{FiO}_{2} \mathrm{OLV}$ on oxygenation and pulmonary shunt}

Data acquired at each time point were statistically analyzed using analysis of variance. The results showed that, during OLV, patients in Group C and B had lower levels of $\mathrm{PaO}_{2}, \mathrm{SaO}_{2}, \mathrm{SpO}_{2}, \mathrm{MAP}$, and Qs/Qt than those in Group A (Table 3). At T2 (OLV $10 \mathrm{~min}$ ), patients in Group $\mathrm{C}$ and $\mathrm{B}$ exhibited a lower $\mathrm{PaO}_{2} / \mathrm{FiO}_{2}$ than those in Group A, without any statistical difference at other time points (Table 3 ).

\section{Effects of PGE1 nebulization of ventilated lungs under different $\mathrm{FiO}_{2}$ OLV on inflammatory factors and postoperative characteristics}

Data of inflammatory factors collected at each time point were compared by analysis of variance. The results presented that the IL- 6 levels of patients in different groups were different at T8 $(\mathrm{F}=3.431, P=0.038)$, with the level of IL-6 in Group C being lower than that of Group B and A (Table 4 and Fig. 2A). MDA levels among the three groups were different at $\mathrm{T} 5(\mathrm{~F}=4.692, P=0.012)$ and $\mathrm{T} 7$ $(\mathrm{F}=5.906, P=0.004)$, with the MDA level of Group $\mathrm{C}$ being lower than that of Group B and A at T5, and the MDA level of Group $C$ and $B$ being lower than that of Group A at T7 (Table 4 and Fig. 2B). In terms of TNF- $\alpha$ level, patients in Group $C$ had a lower level than Group B and $A$ at T8 $(F=3.598, P=0.033)$ (Table 4 and Fig. $2 \mathrm{C}$ ). Differences in the level of SOD were not statistically significant (Table 4 and Fig. 2D). Regarding postoperative characteristics, the lung infection scores of patients in Group C and B were lower than those of Group A, and the difference was statistically significant $(P<0.05)$ (Table 5). In addition, there was no significant difference in lung infection scores, complications, length of stay in hospital and ICU, and grade of wound healing between patients in Group $\mathrm{C}$ and those who did not use PGE1 (Table 6).

\section{Discussion}

PGE1 has been reported to maintain adequate oxygenation among patients under $60 \% \mathrm{FiO}_{2}$ one-lung ventilation (OLV) [15]. However, the effects of PGE1 on patients under $40 \% \mathrm{FiO}_{2} \mathrm{OLV}$ remain uncertain. We intended to study the effects of PGE1 on pulmonary shunt and oxygenation of patients under $40 \% \mathrm{FiO}_{2} \mathrm{OLV}$ and provide a reference concentration of PGE1. Although the levels of $\mathrm{PaO}_{2}, \mathrm{SaO}_{2}, \mathrm{MAP}$, and $\mathrm{SaO}_{2}$ decreased when the concentration of $\mathrm{FiO}_{2}$ decreased from 60 to $40 \%, \mathrm{PaO}_{2}$ and $\mathrm{SaO}_{2}$ remained at a safe level. Furthermore, no statistical difference among patients treated with $60 \% \mathrm{FiO}_{2}$ and $40 \%$ $\mathrm{FiO}_{2}$ was observed regarding $\mathrm{PaCO}_{2}, \mathrm{ETCO}_{2}$, and PAW levels. In addition, the level of $\mathrm{PaO}_{2} / \mathrm{FiO}_{2}$ decreased at $\mathrm{T} 2$, but the difference at other moments was not statistically significant, with Qs/Qt of patients treated with $40 \% \mathrm{FiO}_{2}$ being lower than $60 \%$. Those results indicated that the concentration of $\mathrm{FiO}_{2}$ could be reduced from 60 to $40 \%$. In addition, among patients treated with $40 \%$ $\mathrm{FiO}_{2}$, increasing the concentration of PGE1 could reduce the levels of IL-6, MDA, and TNF- $\alpha .40 \% \mathrm{FiO}_{2}+0.2 \mu \mathrm{g} /$ $\mathrm{kg}$ PGE1 is recommended as a better combination on account of its effects on the inflammatory factors.

Table 2 Characteristic of patients with esophageal cancer [n (\%)/Mean \pm SD]

\begin{tabular}{|c|c|c|c|c|c|}
\hline Characteristic & All $(n=90)$ & A group $(n=30)$ & C group $(n=30)$ & B group $(n=30)$ & $P$ \\
\hline Gender & & & & & 0.627 \\
\hline Male & $71(78.89)$ & $25(83.33)$ & $22(73.33)$ & $24(80.00)$ & \\
\hline Female & $19(21.11)$ & $5(16.67)$ & $8(26.67)$ & $6(20.00)$ & \\
\hline Age, year & $63.32 \pm 6.46$ & $63.20 \pm 6.03$ & $64.60 \pm 5.91$ & $62.17 \pm 7.33$ & 0.346 \\
\hline $\mathrm{BMI}, \mathrm{kg} / \mathrm{m}^{2}$ & $23.16 \pm 2.91$ & $22.60 \pm 3.21$ & $23.80 \pm 2.55$ & $23.08 \pm 2.88$ & 0.276 \\
\hline Duration of surgery, min & $209.20 \pm 60.92$ & $213.53 \pm 66.25$ & $192.23 \pm 36.02$ & $221.83 \pm 72.26$ & 0.152 \\
\hline Duration of OLV, min & $173.57 \pm 50.75$ & $177.40 \pm 43.84$ & $159.90 \pm 39.30$ & $183.40 \pm 64.26$ & 0.177 \\
\hline
\end{tabular}

BMI, Body mass index; OLV, one-lung ventilation

$\mathrm{A}, 60 \% \mathrm{FiO}_{2}+0.1 \mu \mathrm{g} / \mathrm{kg} \mathrm{PGE}_{1} ; \mathrm{B}, 40 \% \mathrm{FiO}_{2}+0.1 \mu \mathrm{g} / \mathrm{kg} \mathrm{PGE}{ }_{1} ; \mathrm{C}, 40 \% \mathrm{FiO}_{2}+0.2 \mu \mathrm{g} / \mathrm{kg} \mathrm{PGE}{ }_{1}$ 
Table 3 The levels of $\mathrm{PaO}_{2}, \mathrm{PaO}_{2} / \mathrm{FiO}_{2}, \mathrm{SaO}_{2}, \mathrm{SPO}_{2}, \mathrm{ETCO}_{2}, \mathrm{PaCO}_{2}, \mathrm{MAP}, \mathrm{PAW}$ and QS/QT among three groups

\begin{tabular}{|c|c|c|c|c|c|c|c|}
\hline Indicator & Group & $\mathrm{T} 1$ & $\mathrm{~T} 2$ & T3 & $\mathrm{T} 4$ & T5 & T6 \\
\hline \multicolumn{8}{|c|}{$\mathrm{PaO}_{2^{*}}, \mathrm{mmHg}$} \\
\hline & A & $271.5 \pm 37.5$ & $153.4 \pm 32.2$ & $132.0 \pm 28.5$ & $121.0 \pm 27.3$ & $115.4 \pm 34.9$ & $153.4 \pm 45.3$ \\
\hline & B & $175.0 \pm 51.1^{\mathrm{a}}$ & $88.7 \pm 27.6^{a}$ & $89.2 \pm 29.4^{\mathrm{a}}$ & $74.4 \pm 17.8^{\mathrm{a}}$ & $81.4 \pm 21.4^{\mathrm{a}}$ & $99.5 \pm 25.0^{a}$ \\
\hline & C & $172.5 \pm 90.8^{\mathrm{a}}$ & $84.9 \pm 17.1^{\mathrm{a}}$ & $82.3 \pm 15.9^{a}$ & $76.5 \pm 17.5^{\mathrm{a}}$ & $80.1 \pm 25.3^{a}$ & $101.1 \pm 22.0^{\mathrm{a}}$ \\
\hline \multicolumn{8}{|c|}{$\mathrm{PaO}_{2} / \mathrm{FiO}_{2}, \mathrm{mmHg}$} \\
\hline & A & $452.5 \pm 62.4$ & $255.6 \pm 53.6$ & $219.9 \pm 47.5$ & $201.8 \pm 45.5$ & $192.4 \pm 58.3$ & $255.6 \pm 75.6$ \\
\hline & B & $437.4 \pm 127.8$ & $221.8 \pm 69.0^{a}$ & $222.9 \pm 73.6$ & $185.9 \pm 44.4$ & $203.5 \pm 53.5$ & $248.9 \pm 62.5$ \\
\hline & C & $397.6 \pm 142.8$ & $212.3 \pm 42.8^{a}$ & $205.7 \pm 39.7$ & $191.3 \pm 43.9$ & $200.2 \pm 63.4$ & $252.8 \pm 54.9$ \\
\hline \multicolumn{8}{|l|}{$\mathrm{SaO}_{2}, \%$} \\
\hline & A & $100.0 \pm 0.0$ & $98.8 \pm 0.9$ & $98.4 \pm 1.3$ & $97.5 \pm 1.5$ & $97.9 \pm 1.4$ & $98.9 \pm 1.4$ \\
\hline & B & $99.3 \pm 0.7$ & $95.2 \pm 2.4^{\mathrm{a}}$ & $95.2 \pm 2.9^{\mathrm{a}}$ & $93.6 \pm 3.1^{a}$ & $95.0 \pm 2.1^{\mathrm{a}}$ & $97.2 \pm 1.7^{\mathrm{a}}$ \\
\hline & C & $98.6 \pm 2.3$ & $95.4 \pm 2.8^{\mathrm{a}}$ & $94.8 \pm 2.6^{\mathrm{a}}$ & $93.9 \pm 3.0^{\mathrm{a}}$ & $94.5 \pm 2.8^{\mathrm{a}}$ & $97.2 \pm 1.7^{\mathrm{a}}$ \\
\hline \multicolumn{8}{|l|}{$\mathrm{SpO}_{2}, \%$} \\
\hline & A & $99.5 \pm 0.7$ & $99.1 \pm 1.1$ & $98.2 \pm 3.0$ & $98.3 \pm 1.5$ & $98.3 \pm 1.5$ & $99.4 \pm 0.9$ \\
\hline & B & $99.2 \pm 1.2$ & $97.1 \pm 2.2^{\mathrm{a}}$ & $96.6 \pm 2.1^{a}$ & $95.2 \pm 2.4^{\mathrm{a}}$ & $96.3 \pm 2.1^{a}$ & $98.1 \pm 1.5$ \\
\hline & C & $98.0 \pm 5.9$ & $96.4 \pm 4.1^{\mathrm{a}}$ & $95.4 \pm 4.1^{\mathrm{a}}$ & $94.6 \pm 4.3^{\mathrm{a}}$ & $95.3 \pm 3.5^{\mathrm{a}}$ & $97.4 \pm 4.1$ \\
\hline \multicolumn{8}{|c|}{$\mathrm{PaCO}_{2}, \mathrm{mmHg}$} \\
\hline & A & $42.9 \pm 6.0$ & $43.3 \pm 6.2$ & $41.8 \pm 5.8$ & $40.1 \pm 5.8$ & $41.6 \pm 6.3$ & $39.5 \pm 6.8$ \\
\hline & B & $46.2 \pm 18.1$ & $46.3 \pm 7.2$ & $43.8 \pm 4.9$ & $42.5 \pm 5.2$ & $40.9 \pm 6.1$ & $39.4 \pm 4.7$ \\
\hline & C & $43.4 \pm 4.9$ & $48.9 \pm 8.4$ & $47.1 \pm 7.8$ & $42.6 \pm 6.0$ & $40.3 \pm 5.6$ & $39.6 \pm 6.0$ \\
\hline \multicolumn{8}{|c|}{$\mathrm{ETCO}_{2}, \mathrm{mmHg}$} \\
\hline & A & $35.4 \pm 5.8$ & $36.8 \pm 4.6$ & $35.7 \pm 4.1$ & $34.7 \pm 4.0$ & $35.1 \pm 4.4$ & $34.4 \pm 4.4$ \\
\hline & B & $35.2 \pm 3.6$ & $36.3 \pm 4.7$ & $35.6 \pm 4.0$ & $33.9 \pm 4.6$ & $33.1 \pm 4.4$ & $33.6 \pm 3.3$ \\
\hline & C & $35.8 \pm 5.9$ & $38.3 \pm 7.4$ & $37.7 \pm 7.5$ & $35.1 \pm 6.0$ & $33.7 \pm 6.3$ & $33.8 \pm 6.5$ \\
\hline \multicolumn{8}{|c|}{$\mathrm{MAP}_{*}, \mathrm{mmHg}$} \\
\hline & A & $102.1 \pm 14.7$ & $96.5 \pm 16.0$ & $92.6 \pm 16.3$ & $94.1 \pm 22.9$ & $95.6 \pm 21.3$ & $89.3 \pm 26.5$ \\
\hline & B & $72.6 \pm 9.1^{\mathrm{a}}$ & $76.8 \pm 11.5^{a}$ & $78.4 \pm 13.5^{\mathrm{a}}$ & $77.2 \pm 11.8^{\mathrm{a}}$ & $70.3 \pm 11.2^{\mathrm{a}}$ & $67.5 \pm 10.1^{\mathrm{a}}$ \\
\hline & C & $77.3 \pm 12.1^{\mathrm{a}}$ & $83.9 \pm 11.8^{\mathrm{ab}}$ & $84.8 \pm 12.0^{\mathrm{ab}}$ & $80.8 \pm 11.1^{\mathrm{a}}$ & $72.3 \pm 9.5^{\mathrm{a}}$ & $68.7 \pm 10.5^{a}$ \\
\hline \multicolumn{8}{|c|}{$\mathrm{PAW}, \mathrm{cmH}_{2} \mathrm{O}$} \\
\hline & A & $14.9 \pm 3.2$ & $22.5 \pm 3.7$ & $23.0 \pm 3.4$ & $23.6 \pm 4.5$ & $24.3 \pm 4.5$ & $24.3 \pm 3.9$ \\
\hline & B & $15.1 \pm 3.7$ & $21.9 \pm 4.9$ & $21.4 \pm 4.9$ & $22.1 \pm 5.9$ & $21.8 \pm 4.9$ & $22.0 \pm 3.5$ \\
\hline & C & $16.6 \pm 4.6$ & $22.1 \pm 4.2$ & $22.1 \pm 3.9$ & $22.7 \pm 4.0$ & $23.2 \pm 3.8$ & $24.1 \pm 5.0$ \\
\hline \multicolumn{8}{|l|}{$\mathrm{Qs} / \mathrm{Qt}$ * } \\
\hline & A & $11.5 \pm 1.7$ & $16.8 \pm 1.4$ & $17.8 \pm 1.2$ & $18.4 \pm 1.2$ & $18.5 \pm 1.5$ & $17.0 \pm 1.9$ \\
\hline & B & $7.8 \pm 2.4^{\mathrm{a}}$ & $14.4 \pm 2.6^{a}$ & $14.7 \pm 2.0^{\mathrm{a}}$ & $16.0 \pm 2.0^{\mathrm{a}}$ & $15.7 \pm 2.1^{\mathrm{a}}$ & $15.8 \pm 1.4^{\mathrm{a}}$ \\
\hline & C & $7.8 \pm 2.6^{\mathrm{a}}$ & $14.0 \pm 2.9^{\mathrm{a}}$ & $14.5 \pm 2.4^{\mathrm{a}}$ & $15.2 \pm 1.6^{\mathrm{a}}$ & $16.2 \pm 1.6^{\mathrm{a}}$ & $15.3 \pm 2.2^{\mathrm{a}}$ \\
\hline
\end{tabular}

${ }^{a} P<0.05$ compared with Group A; ${ }^{b} P<0.05$ compared with Group $B$; *there is a difference at $T 1$. (baseline), and the subsequent time points are adjusted with the level at $\mathrm{T} 1$

T1, pre-nebulization, T2, one-lung ventilation (OLV) $10 \mathrm{~min}$, T3: OLV $15 \mathrm{~min}$, T4: OLV $30 \mathrm{~min}$, T5: OLV $60 \mathrm{~min}$, T6: OLV $120 \mathrm{~min}$

$\mathrm{PaO}_{2}$, partial pressure of arterial oxygen; $\mathrm{FiO}_{2}$, fraction of inspiration $\mathrm{O}_{2} ; \mathrm{SaO}_{2}$, arterial oxygen saturation; $\mathrm{SpO}_{2}$, percutaneous oxygen saturation; $\mathrm{PaCO}$, arterial partial pressure of carbon dioxide; $\mathrm{ETCO}_{2}$, end-tidal carbon dioxide; $\mathrm{MAP}$, mean arterial pressure; $\mathrm{PAW}$, airway pressure; $\mathrm{A}, 60 \% \mathrm{FiO}_{2}+0.1 \mu \mathrm{\mu g} / \mathrm{kg} \mathrm{PGE}, \mathrm{B}_{1}, 40 \%$ FiO ${ }_{2}+0.1 \mu \mathrm{gg} / \mathrm{kg}$ $\mathrm{PGE}_{1} ; \mathrm{C}, 40 \% \mathrm{FiO}_{2}+0.2 \mu \mathrm{g} / \mathrm{kg} \mathrm{PGE}_{1}$

Previous research illustrated that $58 \%$ of patients under $50 \% \mathrm{FiO}_{2} \mathrm{OLV}$ had hypoxemia and needed higher $\mathrm{FiO}_{2}$ to maintain $95 \% \mathrm{SpO}_{2}$ [20]. However, our result showed that no patient $\left(\mathrm{FiO}_{2}=40 \%+0.2 \mu \mathrm{g} / \mathrm{kg}\right.$ PGE1 $)$ developed hypoxemia, indicating that PGE1 could be conducive to maintaining adequate oxygenation under $40 \% \mathrm{FiO}_{2}$ OLV.
During OLV, blood flow is distributed in the collapsed lung without ventilation, and the ventilation/perfusion ratio $(\mathrm{V} / \mathrm{Q})$ is almost zero, which results in pulmonary blood flow, without oxygenation, flowing directly into the left atrium and then into the systemic circulation, causing pulmonary shunt [14]. This study showed that once OLV was initiated, the patients' level of Qs/Qt declined 
Table 4 Levels of inflammatory biomarkers

\begin{tabular}{llcccc}
\hline Biomarkers & Group & T1 & T5 & T7 & T8 \\
\hline $\mathrm{IL}-6, \mathrm{pg} / \mathrm{mL}$ & A & $5.15 \pm 2.76$ & $23.78 \pm 4.51$ & $38.45 \pm 10.59$ & $64.97 \pm 7.22$ \\
& B & $4.96 \pm 2.49$ & $23.86 \pm 4.97$ & $39.53 \pm 6.84$ & $58.54 \pm 7.42^{\mathrm{a}}$ \\
$\mathrm{MDA}, \mathrm{nmol} / \mathrm{mL}$ & $\mathrm{C}$ & $4.92 \pm 2.62$ & $23.13 \pm 4.04$ & $37.52 \pm 5.49$ & $54.63 \pm 7.11^{\mathrm{ab}}$ \\
& A & $7.95 \pm 3.08$ & $7.77 \pm 2.40$ & $8.00 \pm 2.73$ & $7.02 \pm 1.93$ \\
$\mathrm{SOD}, \mathrm{U} / \mathrm{mL}$ & $\mathrm{B}$ & $6.54 \pm 2.54$ & $6.73 \pm 2.88^{\mathrm{a}}$ & $5.7 \pm 2.05^{\mathrm{a}}$ & $5.92 \pm 2.53$ \\
& $\mathrm{C}$ & $6.34 \pm 2.48$ & $5.68 \pm 1.88^{\mathrm{ab}}$ & $5.68 \pm 2.22^{\mathrm{a}}$ & $6.65 \pm 2.43$ \\
& A & $60.13 \pm 9.32$ & $57.12 \pm 13.18$ & $56.06 \pm 10.26$ & $58.21 \pm 12.41$ \\
$\mathrm{TNF}-\mathrm{a}, \mathrm{pg} / \mathrm{mL}$ & $\mathrm{B}$ & $64.29 \pm 7.28$ & $63.09 \pm 7.4$ & $60.44 \pm 7.05$ & $61.83 \pm 4.83$ \\
& $\mathrm{C}$ & $64.32 \pm 7.57$ & $61.17 \pm 7.2$ & $60.99 \pm 7.16$ & $63.07 \pm 6.07$ \\
& A & $1.00 \pm 0.40$ & $1.89 \pm 0.91$ & $2.68 \pm 0.70$ & $3.03 \pm 0.65$ \\
& B & $0.82 \pm 0.23$ & $1.88 \pm 0.4$ & $2.66 \pm 0.45$ & $3.3 \pm 0.86$ \\
& C & $0.94 \pm 0.49$ & $1.91 \pm 0.58$ & $2.5 \pm 0.35$ & $2.81 \pm 0.55^{\mathrm{ab}}$ \\
\hline
\end{tabular}

${ }^{a} P<0.05$ compared with Group $A ;{ }^{b} P<0.05$ compared with Group B

IL-6, interleukin-6; MDA, malondialdehyde; SOD, superoxide dismutase; TNF-a, tumor necrosis factor- $a$

T1, pre-nebulization; T5, OLV $60 \mathrm{~min} ; \mathrm{T7}, \mathrm{TLV} 30 \mathrm{~min} ; \mathrm{T} 8,24 \mathrm{~h}$ after surgery

$\mathrm{A}, 60 \% \mathrm{FiO}_{2}+0.1 \mu \mathrm{g} / \mathrm{kg} \mathrm{PGE}{ }_{1} ; \mathrm{B}, 40 \% \mathrm{FiO}_{2}+0.1 \mu \mathrm{g} / \mathrm{kg} \mathrm{PGE}{ }_{1} ; \mathrm{C}, 40 \% \mathrm{FiO}_{2}+0.2 \mu \mathrm{g} / \mathrm{kg} \mathrm{PGE}$

compared to before, which is consistent with the previous research. Inhaling PEG1, a kind of selective pulmonary artery dilator, by ultrasonic atomization during OLV could dilate the pulmonary artery, which causes stealing blood from the shunt area to the non-shunt area, reducing intrapulmonary shunt $[21,22]$. In addition, a previous study demonstrated that PGE1 could decrease pulmonary shunt and increase $\mathrm{PaO}_{2}$ in a dose-dependent manner during OLV [11]. The results showed that the Qs/Qt of patients using $0.2 \mu \mathrm{g} / \mathrm{kg}$ PGE1 and $0.1 \mu \mathrm{g} /$ kg PGE1 under the condition of $40 \% \mathrm{FiO}_{2}$ was significantly lower than that of patients using $0.1 \mu \mathrm{g} / \mathrm{kg}$ PGE1 under $60 \% \mathrm{FiO}_{2}$. This may be because pre-nebulization of PGE1 to the ventilated lung of OLV during two-lung ventilation could reduce shunt and improve oxygenation. However, our results showed that there was no statistical difference in the levels of Qs/Qt and $\mathrm{PaO}_{2} / \mathrm{FiO}_{2}$ between patients treated by $0.2 \mu \mathrm{g} / \mathrm{kg}$ PGE1 and $0.1 \mu \mathrm{g} / \mathrm{kg}$ PGE1 under $40 \% \mathrm{FiO}_{2}$, suggesting that $0.1 \mu \mathrm{g} / \mathrm{kg}$ and $0.2 \mu \mathrm{g} / \mathrm{kg}$ PGE1 would maintain sufficient oxygenation, and further studies are needed to explore whether the mechanism of PGE1 is different under different concentrations of $\mathrm{FiO}_{2}$. In a word, our research results showed that even under $40 \% \mathrm{FiO}_{2}$ OLV, PGE1 could keep lower pulmonary shunt. The mechanisms may be multifaceted. It has been proved experimentally that hypoxic pulmonary vasoconstriction (HPV) could improve oxygenation function in vivo by reducing intrapulmonary shunt $[23,24]$. We speculate that PGE1 might affect Qs/Qt by regulating HPV.

Patients treated with $40 \% \mathrm{FiO}_{2}$ had lower levels of IL- 6 and MDA than those who used $60 \% \mathrm{FiO}_{2}$. In addition, we found that patients receiving $0.2 \mu \mathrm{g} / \mathrm{kg}$ PGE1 had lower levels of IL-6, MDA, and TNF- $\alpha$ than those receiving $0.1 \mu \mathrm{g} / \mathrm{kg}$ PGE1 under $40 \% \mathrm{FiO}_{2}$. Previous research exhibited that MDA levels were indirect indicators of oxidative stress, and MDA was associated with lung injury [25]. Animal experiments and clinical studies showed that intravenous infusion of PGE1 could lower serum IL- 6 and TNF- $\alpha$ levels, reducing organ inflammatory damage $[26,27]$. Considering the effects of the inflammatory factors mentioned, $40 \% \mathrm{FiO}_{2}+0.2 \mu \mathrm{g} / \mathrm{kg}$ PGE1 is recommended as a better combination, which may decrease the risk of infection at the time point we have observed.

Prior research indicated that $60 \% \mathrm{FiO}_{2}+0.1 \mu \mathrm{g} / \mathrm{kg}$ PGE1 could maintain adequate oxygenation during OLV, improving oxidative stress and complications after OLV. This study further found that $0.1 \mu \mathrm{g} / \mathrm{kg}$ and $0.2 \mu \mathrm{g} / \mathrm{kg}$ PGE1 could be adopted to maintain the patients' oxygenation under $40 \% \mathrm{FiO}_{2}$. Additionally, patients under $40 \%$ $\mathrm{FiO}_{2}$ could benefit more from $0.2 \mu \mathrm{g} / \mathrm{kg}$ PGE1 than from $0.1 \mu \mathrm{g} / \mathrm{kg}$ PGE1 in terms of inflammatory factors.

\section{Limitation}

Nevertheless, several limitations in this study could not be ignored. Firstly, further subgroup analysis based on complications, age, or gender was unable to be performed due to the small sample size. Secondly, participants with pulmonary dysfunction were not be enrolled in this study. Whether the recommended combination $\left(40 \% \mathrm{FiO}_{2}+0.2 \mu \mathrm{g} / \mathrm{kg}\right.$ PGE1) is suitable for different populations remains to be further verified. Thirdly, we used $\mathrm{ScvO}_{2}$ instead of $\mathrm{SvO}_{2}$ in the calculation of shunt 


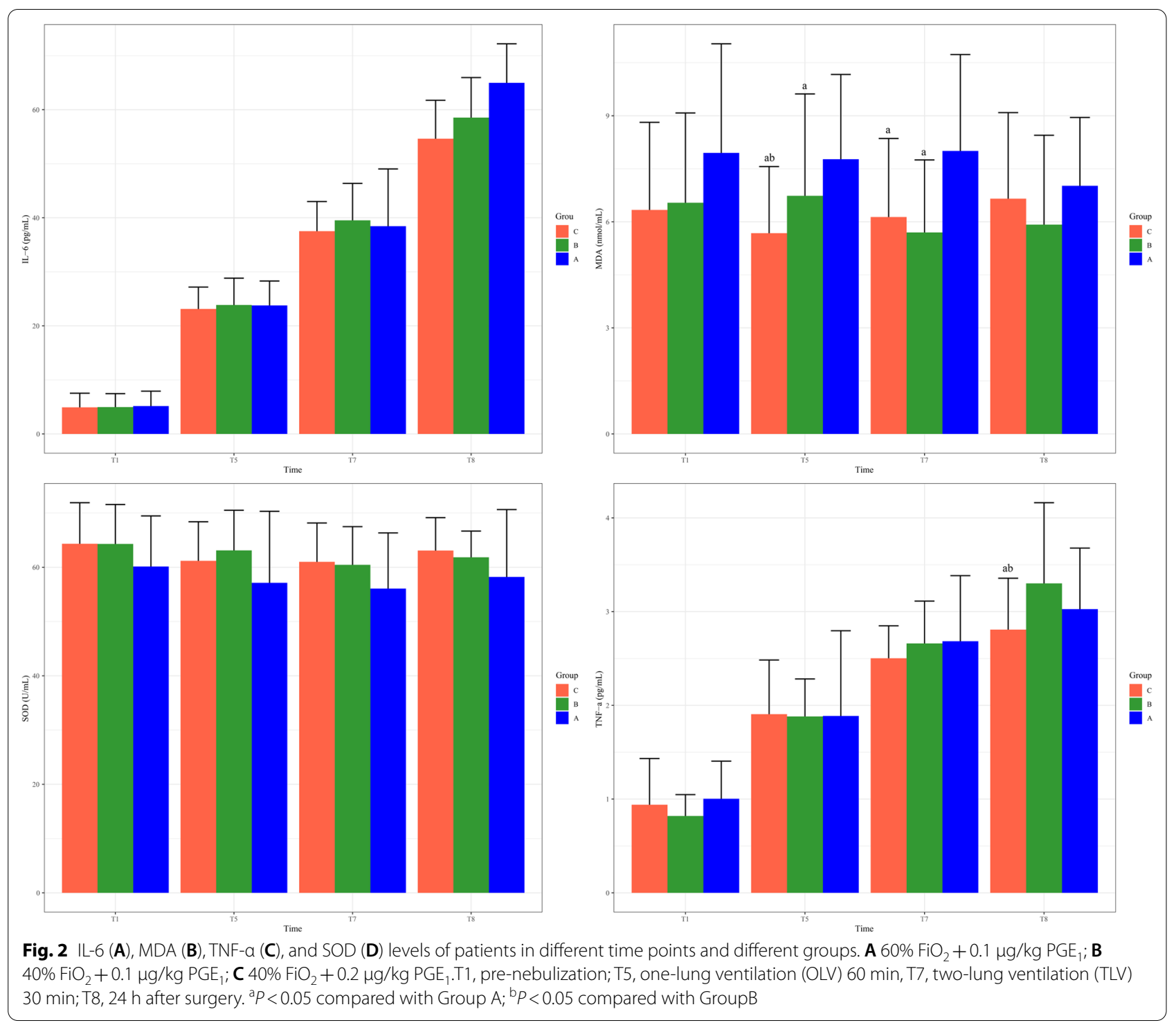

fraction. $\mathrm{ScvO}_{2}$ measures the oxygen saturation of the superior vena cava, while $\mathrm{SvO}_{2}$ measures the oxygen saturation of the whole body, including the abdomen and lower extremities, so the absolute value is different. Using $\mathrm{ScvO}_{2}$ to estimate $\mathrm{SvO}_{2}$ in calculating the shunt fraction was imperfect, and $\mathrm{ScvO}_{2}$ depended on catheter placement, patient anatomy and physiological state [17]. Fourthly, we speculated that pre-nebulization of PGE1 to the ventilated lung of OLV during two-lung ventilation could reduce shunt and improve oxygenation, but $\mathrm{FiO}_{2}$ changes may also have an impact on the shunt. Based on the existing results in this article, we are not sure whether the reduction in the shunt fraction is affected by PGE1. More rigorously designed prospective researches with larger sample sizes are required to confirm our results.

\section{Conclusion}

PGE1 nebulized on the ventilated lung and $\mathrm{FiO}_{2}$ reduced to $40 \%$ for OLV could reduce the shunt fraction and maintain oxygenation. We recommend a PGE1 concentration of $0.2 \mu \mathrm{g} / \mathrm{kg}$, which could reduce the levels of inflammatory factors IL-6, MDA and TNF- $\alpha$ during surgery to a certain extent. 
Table 5 Postoperative characteristics of patients in Group A, C and B $\left[M\left(Q_{1}, Q_{3}\right) / n(\%)\right]$

\begin{tabular}{|c|c|c|c|c|c|}
\hline Characteristics & All $(n=90)$ & A group $(n=30)$ & B group $(n=30)$ & C group $(n=30)$ & $P$ \\
\hline Score for lung infection & $2.53(1.6,4.5)$ & $4.0(3.0,4.7)$ & $1.0(1.0,2.7)^{*}$ & $2.0(1.0,3.0)^{*}$ & $<0.001$ \\
\hline \multicolumn{6}{|l|}{ Complication } \\
\hline Pleural effusion & $2(2.22)$ & $0(0.00)$ & $2(6.67)$ & $0(0.00)$ & 0.326 \\
\hline Pneumothorax & $1(1.11)$ & $0(0.00)$ & $0(0.00)$ & $1(3.33)$ & 1.000 \\
\hline Anastomotic leakage & $3(3.33)$ & $0(0.00)$ & $2(6.67)$ & $1(3.33)$ & 0.770 \\
\hline Incision infection & $1(1.11)$ & $0(0.00)$ & $0(0.00)$ & $1(3.33)$ & 1.000 \\
\hline LOS in hospital, day & $21.5(19.0,25.7)$ & $21.0(18.3,21.0)$ & $21.0(19.0,24.7)$ & $22.0(19.0,25.7)$ & 0.175 \\
\hline LOS in ICU, day & $1.0(1.0,1.0)$ & $1.0(1.0,1.0)$ & $1.0(1.0,1.0)$ & $1.0(1.0,1.0)$ & 0.372 \\
\hline Grade of wound healing & & & & & 0.318 \\
\hline 1 & $86(95.56)$ & $30(100.00)$ & $29(96.67)$ & $27(90.00)$ & \\
\hline$\geq 2$ & $4(4.44)$ & $0(0.00)$ & $1(3.33)$ & $3(10.00)$ & \\
\hline
\end{tabular}

${ }^{*} P<0.05$ compared with Group A

LOS, Length of stay

$\mathrm{A}, 60 \% \mathrm{FiO}_{2}+0.1 \mu \mathrm{g} / \mathrm{kg} \mathrm{PGE}{ }_{1} ; \mathrm{B}, 40 \% \mathrm{FiO}_{2}+0.1 \mu \mathrm{g} / \mathrm{kg} \mathrm{PGE}{ }_{1} ; \mathrm{C}, 40 \% \mathrm{FiO}_{2}+0.2 \mu \mathrm{g} / \mathrm{kg} \mathrm{PGE}$

Table 6 Postoperative characteristics of patients in Group C and those who did not use PGE1 under 40\% FiO $2\left[M\left(\mathrm{Q}_{1}, \mathrm{Q}_{3}\right) / \mathrm{n}(\%)\right]$

\begin{tabular}{|c|c|c|c|}
\hline Characteristics & $40 \% \mathrm{FiO}_{2}+0$ PGE1 $(n=30)$ & C group $(n=30)$ & $P$ \\
\hline Score for lung infection & $2.00(1.00,3.00)$ & $2.00(1.00,3.00)$ & 0.331 \\
\hline \multicolumn{4}{|l|}{ Complication } \\
\hline Pneumothorax & $0(0.00)$ & $1(3.33)$ & 1.000 \\
\hline Anastomotic leakage & $3(10.00)$ & $1(3.33)$ & 0.612 \\
\hline Incision infection & $0(0.00)$ & $1(3.33)$ & 1.000 \\
\hline LOS in hospital, day & $21.00(19.00,28.00)$ & $22.00(19.00,26.00)$ & 0.894 \\
\hline LOS in ICU, day & $1.00 \pm 0.00$ & $1.03 \pm 0.18$ & 0.326 \\
\hline Grade of wound healing & & & 0.321 \\
\hline 1 & $28(96.55)$ & $27(90.00)$ & \\
\hline 2 & $1(3.45)$ & $2(6.67)$ & \\
\hline 3 & $0(0.00)$ & $1(3.33)$ & \\
\hline
\end{tabular}

LOS, Length of stay

$\mathrm{C}, 40 \% \mathrm{FiO}_{2}+0.2 \mu \mathrm{g} / \mathrm{kg} \mathrm{PGE}$

\section{Abbreviations}

PGE1: Prostaglandin E1; OLV: One-lung ventilation; $\mathrm{FiO}_{2}$ : Fraction of inspiration $\mathrm{O}_{2}$; EC: Esophageal cancer; $\mathrm{PaO}_{2}$ : Partial pressure of arterial oxygen; DLT: Double-lumen tube; VT: Tidal volume; RR: Respiratory rate; $\mathrm{ETCO}_{2}$ : End-tidal carbon dioxide; PEEP: Positive end-expiratory pressure; $\mathrm{BIS}$ : Bispectral index; $\mathrm{SaO}_{2}$ : Arterial oxygen saturation; $\mathrm{SpO}_{2}$ : Percutaneous oxygen saturation; $\mathrm{PaCO}_{2}$ : Arterial partial pressure of carbon dioxide; MAP: Mean arterial pressure; PAW: Airway pressure; $\mathrm{CCO}_{2}$ : Pulmonary capillary blood oxygen content; $\mathrm{CaO}_{2}$ : Arterial blood oxygen content; $\mathrm{CvO}_{2}$ : Mixed venous blood oxygen content; $\mathrm{PvO}_{2}$ : Mixed venous oxygen partial pressure; $\mathrm{SvO}_{2}$ : Mixed venous oxygen saturation; $\mathrm{ScvO}_{2}$ : Central venous oxygen saturation; $\mathrm{P}_{\mathrm{B}}$ : Atmospheric pressure; $\mathrm{P}_{\mathrm{H} 2 \mathrm{O}}$ : $37^{\circ} \mathrm{C}$ water vapor pressure; $\mathrm{R}$ : Respiratory quotient; MDA: Malondialdehyde; SOD: Superoxide dismutase; TNF-a: Tumor necrosis factor-a; IL-6: Interleukin 6; TLV: Two-lung ventilation; CPIS: Clinical pulmonary infection score; $\mathrm{M} \pm \mathrm{SD}$ : Mean \pm standard deviation; SNK: Student-Newman-Keuls.

\section{Authors' contributions}

PYL, LBG, JT, and LJW designed the study. PYL, LBG and JT wrote the manuscript. ZHS, QMB, DJ and ZPX collected, analyzed and interpreted the data. LJW critically reviewed, edited and approved the manuscript. All authors read and approved the final manuscript.

\section{Funding}

This research is supported by the talents program of Jiangsu Cancer Hospital (YC201805).

\section{Availability of data and materials}

The datasets used and/or analyzed during the current study are available from the corresponding author on reasonable request.

\section{Acknowledgements}

Not applicable. 


\section{Declarations}

\section{Ethics approval and consent to participate}

This randomized controlled clinical trial was registered at chictr.org.cn (identifier: ChiCTR1800018288, 09/09/2018), approved by the Ethics Committee of the Nanjing Medical University [2017-550]. Written informed consent has been obtained from all participants.

\section{Consent for publication}

Written informed consent was obtained from the patient for publication of this case report and any accompanying images. A copy of the written consent is available for review by the Editor of this journal.

\section{Competing interests}

The authors declare that they have no competing interests.

Received: 10 Auqust 2021 Accepted: 6 January 2022

Published online: 13 January 2022

\section{References}

1. McGuire S. World cancer report 2014. Geneva, Switzerland: World Health Organization, international agency for research on cancer, WHO Press, 2015. Adv Nutr. 2016;7:418-9.

2. Bray F, Ferlay J, Soerjomataram I, Siegel R, Torre L, Jemal A. Global cancer statistics 2018: GLOBOCAN estimates of incidence and mortality worldwide for 36 cancers in 185 countries. CA Cancer J Clin. 2018:68:394-424.

3. Campos $\mathrm{JH}$, Feider A. Hypoxia during one-lung ventilation-A review and update. J Cardiothorac Vasc Anesth. 2018;32:2330-8.

4. Purohit A, Bhargava S, Mangal V, Parashar VK. Lung isolation, one-lung ventilation and hypoxaemia during lung isolation. Indian J Anaesth. 2015:59:06.

5. Grocott HP, Wills G, Yamashita MH. Dependent lung pulmonary artery hypoplasia as a cause of hypoxia during one-lung ventilation. Anesthesiology. 2021;134:770-1.

6. Ding H-G, Deng Y-Y, Yang R-Q, Wang Q-S, Jiang W-Q, Han Y-L, Huang L-Q Wen M-Y, Zhong W-H, Li X-S. Hypercapnia induces IL-1 $\beta$ overproduction via activation of NLRP3 inflammasome: implication in cognitive impairment in hypoxemic adult rats. J Neuroinflammation. 2018;15:1-16.

7. Choi H, Jeon J, Huh J, Koo J, Yang S, Hwang W. The effects of iloprost on oxygenation during one-lung ventilation for lung surgery: a randomized controlled trial. J Clin Med. 2019;8:982.

8. Lytle FT, Brown DR. Appropriate ventilatory settings for thoracic surgery: intraoperative and postoperative. Semin Cardiothorac Vasc Anesth. 2008; 12:97-108.

9. Jaffal K, Six S, Zerimech F, Nseir S. Relationship between hyperoxemia and ventilator associated pneumonia. Ann Transl Med. 2017:5:453.

10. Brassard CL, Lohser J, Donati F, Bussières JS. Step-by-step clinical management of one-lung ventilation: continuing professional development. Can J Anaesth. 2014;61:1103-21.

11. Chen TL, Lee YT, Wang MJ, Lee JM, Lee YC, Chu SH. Endothelin-1 concentrations and optimisation of arterial oxygenation and venous admixture by selective pulmonary artery infusion of prostaglandin E1 during thoracotomy. Anaesthesia. 1996;51:422-6.

12. Sood BG, Keszler M, Garg M, Klein JM, Ohls R, Ambalavanan N, Cotten CM, Malian M, Sanchez PJ, Lakshminrusimha S. Inhaled PGE 1 in neonates with hypoxemic respiratory failure: two pilot feasibility randomized clinical trials. Trials. 2014;15:1-14.

13. Adatia I, Haworth SG, Wegner M, Barst RJ, Ivy D, Stenmark KR, Karkowsky A, Rosenzweig E, Aguilar C. Clinical trials in neonates and children: report of the pulmonary hypertension academic research consortium pediatric advisory committee. Pulm Circ. 2013;3:252-66.

14. Yao W, Yang M, Cheng Q, Shan S, Yang B, Han Q, Ma J. Effect of pressurecontrolled ventilation-volume guaranteed on one-lung ventilation in elderly patients undergoing thoracotomy. Med Sci Monitor. 2020;26:e921411-7

15. Li P, Gu L, Bian Q, Tan J, Jiao D, Wu F, Xu Z, Wang L. Effects of prostaglandin $\mathrm{E} 1$ nebulization of ventilated lung under $60 \% \mathrm{O}_{2}$ one lung ventilation on patients' oxygenation and oxidative stress: a randomised controlled trial. Respir Res. 2020;21:1-8.

16. Xu X, Wang X, Ge W, Pan L, Zheng M. The pharmacokinetics of inhaled morphine delivered by an ultrasonic nebulizer in ventilated dogs. J Aerosol Med Pulm Drug Deliv. 2012;25:41-6.

17. Walley KR. Use of central venous oxygen saturation to guide therapy. Am J Respir Crit Care Med. 2011:184:514-20.

18. Hardman J, Bedforth N, Ahmed A, Mahajan R, Aitkenhead A. A physiology simulator: validation of its respiratory components and its ability to predict the patient's response to changes in mechanical ventilation. $\mathrm{Br}$ J Anaesth. 1998;81:327-32

19. Pugin J, Auckenthaler R, Mili N, Janssens J, Lew P, Suter P. Diagnosis of ventilator-associated pneumonia by bacteriologic analysis of bronchoscopic and nonbronchoscopic "blind" bronchoalveolar lavage fluid. Am Rev Respir Dis. 1991;143:1121-9.

20. Yang M, Ahn HJ, Kim K, Kim JA, Chin AY, Kim MJ, Kim HJ. Does a protective ventilation strategy reduce the risk of pulmonary complications after lung cancer surgery?: a randomized controlled trial. Chest. 2011;139:530-7.

21. Afshari A, Bille AB, Allingstrup M: Aerosolized prostacyclins for acute respiratory distress syndrome (ARDS). Cochrane Database Syst Rev; 2017.

22. Liu K, Wang H, Yu S-J, Tu G-W, Luo Z. Inhaled pulmonary vasodilators: a narrative review. Ann Transl Med. 2021;9:597.

23. Lumb A, Slinger P. Hypoxic pulmonary vasoconstriction: physiology and anesthetic implications. Anesthesiology. 2015;122:932-46.

24. Karzai W, Schwarzkopf K. Hypoxemia during one-lung ventilation: prediction, prevention, and treatment. Anesthesiology. 2009:110:1402-11.

25. Tekinbas C, Ulusoy H, Yulug E, Erol MM, Alver A, Yenilmez E, Geze S, Topbas M. One-lung ventilation: for how long? J Thorac Cardiovasc Surg. 2007;134:405-10

26. Gezginci-Oktayoglu S, Orhan N, Bolkent S. Prostaglandin-E1 has a protective effect on renal ischemia/reperfusion-induced oxidative stress and inflammation mediated gastric damage in rats. Int Immunopharmacol. 2016;36:142-50.

27. Tang M, Pan H, Zheng Z, Guo Y, Peng J, Yang J, Luo Y, He J, Yan S, Wang $P$, et al. Prostaglandin E1 protects cardiomyocytes against hypoxiareperfusion induced injury via the miR-21-5p/FASLG axis. Biosci Rep. 2019:39:20190597.

\section{Publisher's Note}

Springer Nature remains neutral with regard to jurisdictional claims in published maps and institutional affiliations.

Ready to submit your research? Choose BMC and benefit from

- fast, convenient online submission

- thorough peer review by experienced researchers in your field

- rapid publication on acceptance

- support for research data, including large and complex data types

- gold Open Access which fosters wider collaboration and increased citations

- maximum visibility for your research: over 100M website views per year

At BMC, research is always in progress.

Learn more biomedcentral.com/submissions 